\section{Uncertain future}

As the latest scheduled deadline for the UK to leave the EU approaches on 31 October, the future for dentistry remains uncertain although some people predict the problems in attracting overseas dentists here will be temporary.

Lithuanian-trained associate Rasa

Zamulaityte who qualified in her home country 12 years ago has been based in Bournemouth for around a decade and feels settled despite uncertainties around Brexit.

'Initially I thought I'd just come to the UK for six or nine months for a change, but then I started studying more, decided to stay and got used to being here. Then I fell in love with an English guy and did not want to go back,'she says.

After signing a contract with a dental corporate for a limited time, Rasa decided to extend her time here and after several years working for the NHS, now works three days a week in a private practice and two days in a NHS practice.

She has permanent residency here and says: 'I don't know how dentistry is going to be affected by Brexit. It depends on how the economy will go post-Brexit and how much patients will be able to afford dentistry.

'I don't feel unsettled by Brexit. It just may be harder for corporates to employ dentists from other countries which may create dentist shortages again.

'Having spoken to colleagues and friends from university back in Lithuania, they have said if they wanted to come and work here, they are not going to apply to come here until the Brexit is done.'

Woodrow warns there are other indirect impacts of Brexit to bear in mind, saying: 'We hear that it's not just about the way it makes people feel here, but also the economic impact of it in terms of the value of earnings now in the UK are not what they were.

'That makes it a less attractive place to work for some people from parts of the EU. The pound is considerably weaker than it was three years ago and that also makes materials more expensive.'

Colosseum Dental's Buergin adds: 'Once we have certainty and we know what Brexit implies, the channel will open up again. It is hopefully a temporary problem.'

\section{References}

1. General Dental Council. Survey of European Qualified Dental Professionals Final Report January 2019. Available at: https://www.gdc-uk.org/about/whatwe-do/research (accessed July 2019).

2. Christie \& Co. The Dental Industry 2018: Staffing, Brexit and The Dentist Shortage. October 2018. Available at: https://www.christie.com/christieMediaLibraries/christie/PDFs-Publications/Dental/ CCO-The-Dental-Industry-2018.pdf?ext=.pdf (accessed July 2019).

3. Professional Standards Authority. Annual review of performance 2017/18: General Dental Council. May 2019. Available at: https://www. professionalstandards.org.uk/docs/default-source/ publications/performance-review---gdc-2017-18. pdf?sfvrsn=16db7420_0 (accessed July 2019).

4. LaingBuisson. Dentistry UK Market Report. January 2019. Available at: https://www.laingbuisson.com/ shop/dentistry/ (accessed July 2019).

\title{
The bells are ringing out for new content
}

The $B D J$ Christmas issue is now a regular feature in the publication calendar, and as in previous years we would like to invite writers to submit content.

Highlights of the 2018 Christmas edition included the research papers Whisky, microwave or hairdryer? Exploring the most efficient way to reduce bacterial colonisation on contaminated toothbrushes and Are dental professionals more likely to consume sweet snacks, over savoury snacks in the workplace?

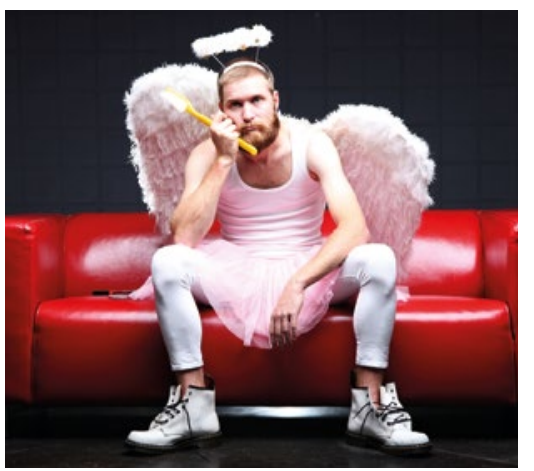

We also published a range of tongue-in-

cheek letters, news and product news stories written by members of the editorial team, all in the spirit and fun of the festive season.

If you have an idea for a funny $B D J$ paper, or a spoof letter or news item, we would like to hear from you. Please email us a description of your proposed topic by 9 September 2019.

We are pleased to consider all kinds of articles, and a Christmas theme is not required.

To submit a proposal, please email News Editor Kate Quinlan on k.quinlan@nature.com. 